\title{
Intense Quench Process in Slow Agitated Water Salt and Polymer Solutions
}

\author{
Nikolai I. Kobasko
}

\section{ABSTRACT}

In the paper it is shown that quenching in slow agitated water salt solution of optimal concentration and in low concentration of inverse solubility polymers is intensive quenching creating maximal temperature gradients at the beginning of cooling. The evidence to support such idea were collected by analyzing quenching process in liquid media where any film boiling process was completely absent. In this case, surface temperature at the beginning of cooling drops closely to saturations temperature of a liquid within the interval 1-2 seconds, independently on nature of water solution, and then during transient nucleate boiling process maintains at the level of boiling point of a liquid which is often called self-regulated thermal process. The computer modeling of such cooling processes provided Kondrat'ev numbered $K n$ which are strongly linear function of time. At the beginning of cooling Kondrat'ev number is almost equal to 1 while average Kondrat'ev number $K n \geq 0.8$. According to US Patent, intensive quenching starts when $K n=0.8$. Based on achieved results, it is possible to perform intensive quenching in slow agitated of low concentration water salt and polymer solutions, usually initiated by hydrodynamic emitters. Along with liquid agitation, emitters generate resonance wave effect which destroys film boiling processes making cooling very uniform and intensive. The proposed IQ process works perfectly when martensite starts temperature $M s>T s$. If saturation temperature $T s \geq M s$, intensive austempering process via cold liquids can be successfully performed to replace slow cooling of molten salts and alkalis by intensive quenching in liquid media.

Keywords: Low water concentration, IQ process, low agitation, Kondrat'ev numbers, hydrodynamic emitters, new technology.

Published Online: May 21, 2021

ISSN: $2684-4451$

DOI :10.24018/ejphysics.2021.3.3.76

Nikolai I. Kobasko *

$\mathrm{PhD}$, Fellow of ASM International, Intensive Technologies Ltd, Kyiv, Ukraine.

(e-mail: nkobasko@gmail.com)

*Corresponding Author

\section{INTRODUCTION}

In last decade, several important findings were made concerning study of the transient nucleate boiling process. One of them is duration of transient nucleate boiling that is proportional to thickness squared, depends on form coefficient, initial temperature, cooling intensity of quench system and is inversely proportional to thermal diffusivity of a material (see (1)) [1], [2]:

$\tau_{n b}=\bar{\Omega} k_{F} \frac{D^{2}}{a}$

It was also established that surface temperature during quenching in water salt and alkali solutions drops within $1-$ 2 seconds close to boiling point of a liquid (see (2)) which is calculated as:

$T_{s f}=T_{s}+\frac{\vartheta_{I}+\vartheta_{I I}}{2} \approx$ const
The value $\Omega$ depends on initial temperature $T_{o}$ and convective heat transfer coefficient $\alpha_{c o n v}$ as shown by (3) [3], [4]:

$$
\bar{\Omega}=0.48+3.21 \ln \frac{\vartheta_{I}}{\vartheta_{I I}}
$$

Here

$\vartheta_{I}=0.293 \cdot\left[\frac{2 \lambda\left(\vartheta_{o}-\vartheta_{I}\right)}{R}\right]^{0.3}$

$\vartheta_{I I}=0.293 \cdot\left[\alpha_{c o n v}\left(\vartheta_{I I}+\vartheta_{u h}\right)\right]^{0.3}$

$\beta=\frac{75 \lambda \odot\left(\rho \odot-\rho^{\prime \prime}\right)^{0.5} g^{0.5}}{\sigma^{0.5}\left(\rho^{\prime \prime} r^{\bullet} W^{\prime \prime}\right)^{0.7} \operatorname{Pr}^{0.2}}$

$\frac{1}{\beta}=0.293 ;$

$\operatorname{Pr}=\frac{v}{a}$ is Prandtl number. 
According to Tolubinsky, the bubble growth rate is function of pressure and does not depend on concentration of water salt solutions (see (7)) [5]:

$$
\frac{W^{\prime \prime}}{W_{0.1}^{\prime \prime}}=\left(\frac{\rho_{0.1}}{\rho^{\prime \prime}}\right)^{2.3+0.5 \lg \frac{P}{P_{c r}}}
$$

$W_{0.1}^{\prime \prime}$ is bubble growth rate at normal pressure $\mathrm{P} ; P_{c r}$ is critical pressure in $\mathrm{Pa} ; \alpha$ is heat transfer coefficient at nucleate boiling $\left(\mathrm{W} / \mathrm{m}^{2} K\right) ; \lambda$ is thermal conductivity of liquid $\left(\frac{W}{m K}\right) ; \sigma$ is surface tension $(N / m) ; g$ is gravity acceleration $\left(\mathrm{m} / \mathrm{s}^{2}\right) ; \rho$ is liquid density $\left(\mathrm{kg} / \mathrm{m}^{3}\right) ; \rho^{\prime \prime}$ is vapor density $\left(\mathrm{kg} / \mathrm{m}^{3}\right) ; q$ is heat flux density $\left(W / m^{2}\right) ; r^{*}$ is heat of vapor formation $(\mathrm{J} / \mathrm{kg}) ; W^{\prime \prime}$ is steam bubble growth rate $(\mathrm{m} / \mathrm{s}) ; T_{o}$ is initial temperature; $v$ is kinematic viscosity $\left(\mathrm{m}^{2} / \mathrm{s}\right) ; a$ is thermal diffusivity of a liquid $\left(\mathrm{m}^{2} / \mathrm{s}\right)$.

In this paper the author is going to find out what is difference between water solutions of optimal concentration such as $\mathrm{NaCl} ; \mathrm{NaOH} ; \mathrm{NaNO}_{2} ; \mathrm{NaNO}_{3} ; \mathrm{Na}_{2} \mathrm{CO}_{3} ; \mathrm{CaCl}_{2}$; $\mathrm{MgCl}_{2}$ and low concentration of inverse solubility polymers when any film boiling process is completely absent. The idea consists in possibility of switching from given solution to any listed quenchant that provides identical and stable result of cooling, temperature fields, stress distribution, and super strengthening effect. All of this is fulfilled if temperature field during quenching in mentioned solutions are identical. It can be done analyzing equations which are provided above.

For liquid in still condition, the convective heat transfer coefficient (HTC) is evaluated by (8) [6]:

$$
\alpha_{\text {conv }}=0.135 \lambda \cdot\left(\frac{g \beta^{\prime} \Delta T}{a v}\right)^{1 / 3}
$$

In contrast to (6), here $\beta^{\prime}$ is volumetric expansion. Convective HTCs in still liquids are approximately equal to $500-1000 \mathrm{~W} / \mathrm{m}^{2} \mathrm{~K}$ while for agitated bath with $1 \mathrm{~m} / \mathrm{s}$ it is equal to $4000 \mathrm{~W} / \mathrm{m}^{2} \mathrm{~K}$. For still liquid condition the convective Biot number $\mathrm{Bi}$ is equal to 0.136 while for agitated liquid $\mathrm{Bi}=1$ when standard probe $12.5 \mathrm{~mm}$ is used. According to Ref. [7], for given convective Biot numbers $\bar{\Omega}=5.1$ and $\bar{\Omega}=3$. The flow and spray convention are considered in [7], [8].

\section{EFFECT PHYSICAL PROPERTIES OF QUENCHANT ON NuClEATE BoILING PROCESS DURATION}

The value $\beta$ in (6) presents physical properties of water and water salt solutions which also includes vapor cooling rate grows W". The last does not depend on water salt concentration (see Table I).

As one can see from Table I, in case of boiling highconcentration solutions of $\mathrm{NaCl}$ and $\mathrm{Na}_{2} \mathrm{CO}_{3}$, their vapor bubble growth rates are the same as for water. In [5] it is noted that the vapor bubble growth rate for boiling aqueous solutions is determined by properties of the solvent (water) and its vapor and is very weakly affected by properties of solved substances, viscosity and Prandtl number of a solution.

TABLE I: COMPARISON OF PARAMETERS OF BOILING PROCESS FOR WATER AND AQUEOUS SALT SOLUTIONS AT NORMAL PRESSURE [5]

\begin{tabular}{cccc}
\hline Substance & $d_{0}, \mathrm{~mm}$ & $f, 1 / \mathrm{s}$ & $W^{\prime \prime}, \mathrm{mm} / \mathrm{s}$ \\
\hline $\begin{array}{c}\text { Water } \\
25 \% \mathrm{NaCl} \\
\text { solution }\end{array}$ & 2.5 & 62 & 155 \\
$\begin{array}{c}29 \% \mathrm{Na}_{2} \mathrm{CO}_{3} \\
\text { solution }\end{array}$ & 2.4 & 64.5 & 155 \\
\hline
\end{tabular}

TABLE II: VALUe $\beta$ Versus PRessure AT CONSTANT TEMPERATURE OF

\begin{tabular}{cccccc}
\multicolumn{7}{c}{ A LIQUID } \\
\hline Pressure, $\mathrm{MPa}$ & 0.1 & 0.2 & 0.3 & 0.4 & 1 \\
\hline$\beta$ & 3.41 & 3.89 & 4.20 & 4.44 & 5.39 \\
\hline
\end{tabular}

For all water salt solutions of optimal concentration, the value $\beta$ varies between 3 and 4 while during quenching in liquid media under pressure $\beta$ exceeds 5 (see Table II). Let us consider how varying $\beta$ within 3 and 6 impacts the duration of transient nucleate boiling process. Calculations show very weak effect (see Table III).

TABLE III: DURATION OF TRANSIENT NUCLEATE BOILING PROCESS IN SECONDS VERSUS PARAMETER $\beta$ AND DIAMETER OF CYLINDER WHEN COOLING FROM $850^{\circ} \mathrm{C}$ In STILl WATER SALT SOLUTION AT $20^{\circ} \mathrm{C}$

\begin{tabular}{ccccc}
\hline Diameter of & \multicolumn{4}{c}{ Duration, $\mathrm{s}$} \\
\cline { 2 - 5 } $\begin{array}{c}\text { Cylinders, } \\
\text { mm }\end{array}$ & $\beta=3$ & $\beta=3.41$ & $\beta=4.44$ & $\beta=6$ \\
\hline 12.5 & 6.292 & 6.316 & 6.358 & 6.516 \\
25 & 21.94 & 22.04 & 22.17 & 22.15 \\
50 & 75.305 & 75.37 & 75.45 & 75.73 \\
\hline
\end{tabular}

The reason for such small effect is extremely large HTCs during boiling process. Transient nucleate boiling process in this case depends on convective HTC or convective Biot number [7].

It should be noted that the duration of the self-regulated thermal process was considered when developing processes for interrupted cooling to monitor conveyor speeds and also is used for developing the new quenching technologies [4]. It considerably depends on convective HTC (see Table IV).

TABLE IV: DURATION OF TRANSIENT NUCLEATE BOILING PROCESS IN SECONDS VERSUS CONVECTIVE HEAT TRANSFER COEFFICIENT AND PARAMETER $\beta$ WHEN COOLING CYLINDER 50 MM DIAMETER FROM $850{ }^{\circ} \mathrm{C}$ IN STILL WATER SALT SOLUTION AT $20^{\circ} \mathrm{C}$

\begin{tabular}{ccccc}
\hline \multicolumn{5}{c}{$850^{\circ} \mathrm{C}$ IN STILL WATER SALT SOLUTION AT $20^{\circ} \mathrm{C}$} \\
\cline { 2 - 5 } HTC & \multicolumn{4}{c}{ Duration, $\mathrm{s}$} \\
$\mathrm{nyyyy} / \mathrm{m}^{3} \mathrm{~K}$ & $\beta=3$ & $\beta=3.41$ & $\beta=4.44$ & $\beta=6$ \\
\hline 500 & 75.305 & 75 & 75.45 & 75.73 \\
3000 & 39.26 & 39.6 & 40.3 & 40.9 \\
5000 & 29.14 & 29.34 & 30.4 & 31 \\
\hline
\end{tabular}

In contrast to duration of transient nucleate boiling process, $\beta$ essentially effects overheat of a boundary layer during nucleate boiling (see (4) and (5)).

Authors [9] came to conclusion that temperature fields during quenching in $14 \% \mathrm{NaCl}$ water solution and $1 \%$ water solution of polyalkylene glycol (PAG) are identical when $\beta=3.41$. That is also true for larger $\beta$ because increase $\beta$ results in decreasing $\vartheta_{I}$ and $\vartheta_{I I}$ (see (4) and (5)). It means that $\mathrm{NaCl} ; \mathrm{NaOH} ; \mathrm{NaNO}_{2} ; \mathrm{NaNO}_{3} ; \mathrm{Na}_{2} \mathrm{CO}_{3}$; 
$\mathrm{CaCl}_{2} ; \mathrm{MgCl}_{2}$ and low concentration of inverse solubility polymers can replace each other to provide almost the same temperature fields during quenching in listed liquid media if film boiling is completely absent. This fact is very important for the practice.

The idea is supported by experimental data below (see Fig. 1 and Fig. 2).

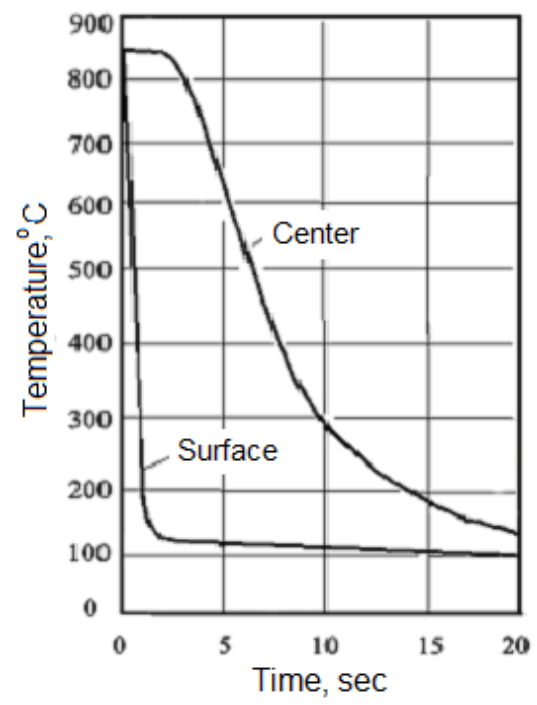

Fig. 1. Cooling curves versus time during quenching cylindrical probe $20 \mathrm{~mm}$ diameter and $80 \mathrm{~mm}$ long in water solution of polyoxyethylene $(0.001 \%)$ at $23^{\circ} \mathrm{C}[10]$.

The film boiling in this experiment was absent due to presence of very thin insulating polymeric layer that decreases initial heat flux density qo below its critical value $q_{c r 1}($ see (7)) and Table V [11]:

$q_{i n}=\frac{q_{o}}{\left(1+2 \frac{\delta}{R} \frac{\lambda}{\lambda_{\text {coat }}}\right)}$

Similar results were obtained during quenching the same probe in $5 \%$ water $\mathrm{NaOH}$ solution (see Fig. 2).

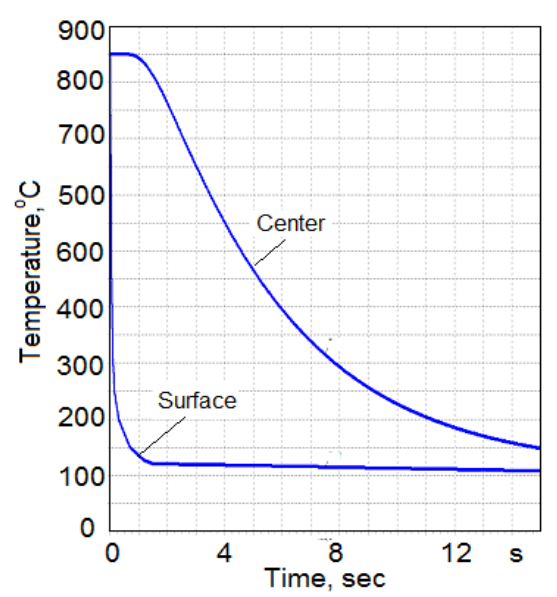

Fig. 2. Cooling curves versus time during quenching cylindrical probe 20 $\mathrm{mm}$ diameter and $80 \mathrm{~mm}$ long in water solution of $\mathrm{NaOH}(5 \%)$ at $20{ }^{\circ} \mathrm{C}$.
TABLE V: COOLING TIME COMPARISON WHEN QUENCHING STANDARD PROBE 12.5 MM DiAMETER IN 1\% WATER SOLUTION OF PAG AND 5\%

\begin{tabular}{cccccc}
\multicolumn{7}{c}{ WATER SOLUTION OF NAOH AT $20^{\circ} \mathrm{C}$} \\
\hline $\begin{array}{c}\text { Cooling } \\
\text { condition }\end{array}$ & $\begin{array}{c}\text { Cooling } \\
\text { time from } \\
850{ }^{\circ} \mathrm{C} \text { to } \\
700{ }^{\circ} \mathrm{C}\end{array}$ & $\begin{array}{c}\text { Cooling } \\
\text { time from } \\
850{ }^{\circ} \mathrm{C} \text { to } \\
600{ }^{\circ} \mathrm{C}\end{array}$ & $\begin{array}{c}\text { Cooling } \\
\text { time from } \\
850{ }^{\circ} \mathrm{C} \text { to } \\
400{ }^{\circ} \mathrm{C}\end{array}$ & $\begin{array}{c}\text { Cooling } \\
\text { time from } \\
850{ }^{\circ} \mathrm{C} \text { to } \\
300{ }^{\circ} \mathrm{C}\end{array}$ & $\begin{array}{c}\text { Cooling } \\
\text { time from } \\
850{ }^{\circ} \mathrm{C} \text { to } \\
200{ }^{\circ} \mathrm{C}\end{array}$ \\
\hline $\begin{array}{c}\text { Cooling } \\
\text { time in s } \\
\text { (Polymer) }\end{array}$ & 3.8 & 5.5 & 7.6 & 9.9 & 15.8 \\
$\begin{array}{c}\text { Cooling } \\
\text { time in s } \\
(5 \% \mathrm{NaOH})\end{array}$ & 2.5 & 4.45 & 6.8 & 7.8 & 11.3 \\
\hline
\end{tabular}

In the second experiment, the film boiling was absent due to presence electrical forces in the double electrical layer. According to the classical statistical thermodynamic, the pressure created by free electrons in metal is directly proportional to the absolute temperature $\mathrm{T}$ and is calculated as [12]:

$$
P=n k T
$$

where $\mathrm{n}$ is a number of electrons in one $\mathrm{sm}^{3}$ of metal; $\mathrm{k}$ is the Boltzmann constant which is equal to $k=1.3806488(13) \times 10^{-23}\left[J K^{-1}\right]$.

As a result, in the double electrical layer [13], [14] a high electrical force appears when quenching metal in electrolyte of optimal concentration (see Fig. 3). Maximal electrical forces are observed in solutions of optimal concentration where critical heat flux densities are maximal.

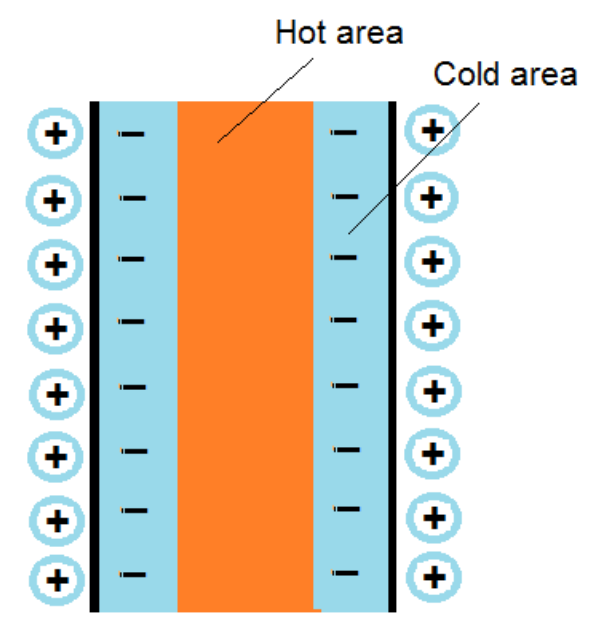

Fig. 3. A double electrical layer taking place suring quenching metal in electrolytes.

As seen from from Fig. 1, Fig. 2 and Table IV, temperature curves are similar when any film boiling process is completely absent. It does not matter what was a reason for absence of film boiling process: thin polymeric insulating layer or electrical forces in the double electrical boundary layer.

\section{ANALYSIS OF KONDRAT'EV NUMBERS FOR WATER SOLUTIONS OF OPTIMAL CONCENTRATION}

As known, Kondrat'ev number $K n$ is responsible for intensity of cooling process and it varies within $0 \leq K n \leq 1$ [15]-[17]. 
According to US Patent [18], cooling process is intensive when $K n$ varies within $0.8 \leq K n \leq 1$.

Let us see what cooling curves and Kondrat'ev numbers $K n$ are during quenching probes $12.5 \mathrm{~mm}$ and $50 \mathrm{~mm}$ diameter in water salt and alkali solutions of optimal concentration. The same consideration will be contributed to low concentration of polymer solutions.

Fig. 4 below shows cooling curves and cooling rates during quenching in $5 \%$ water $\mathrm{NaOH}$ solution at $20^{\circ} \mathrm{C}$. For standard Inconel 600 probe $12.5 \mathrm{~mm}$ diameter the self regulated thermal process is clearly visible and it lasts more than 5 seconds. During the first second, the shock boiling takes place those results in maximum heat flux density (see Fig. 5).

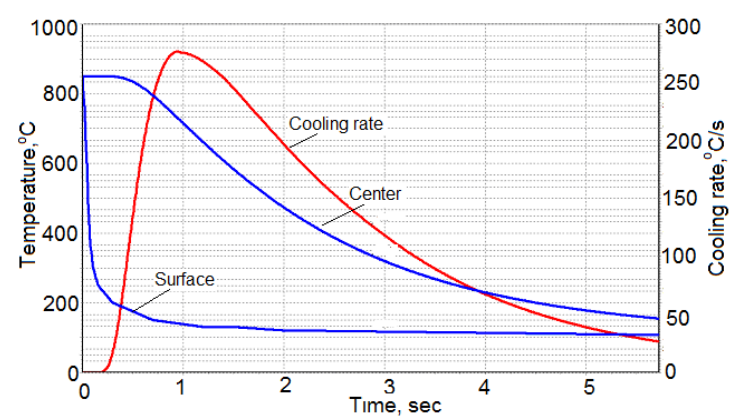

Fig. 4. Cooling curves and cooling rate versus time during quenching cylindrical probe $12.5 \mathrm{~mm}$ diameter in $5 \%$ water solution of $\mathrm{NaOH}$ at $20^{\circ} \mathrm{C}$.

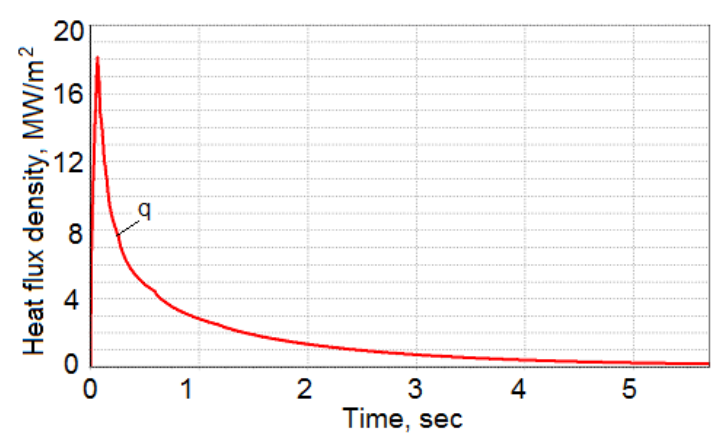

Fig. 5. Heat flux density versus time during quenching cylindrical probe $12.5 \mathrm{~mm}$ diameter in $5 \%$ water solution of $\mathrm{NaOH}$ at $20^{\circ} \mathrm{C}$.

Fig. 6 presents real and effective Kondrat'ev numbers versus time during quenching cylindrical probe $12.5 \mathrm{~mm}$ diameter in $5 \%$ water solution of $\mathrm{NaOH}$ at $20^{\circ} \mathrm{C}$.

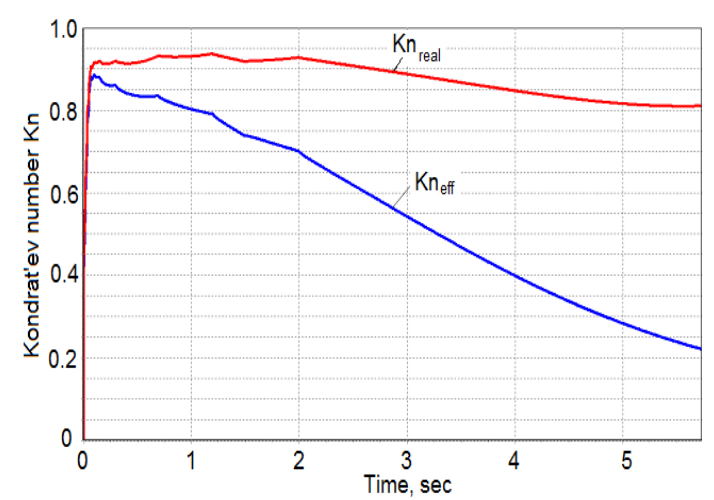

Fig. 5. Real and effective Kondrat'ev numbers versus time during quenching cylindrical probe $12.5 \mathrm{~mm}$ diameter in $5 \%$ water solution of $\mathrm{NaOH}$ at $20^{\circ} \mathrm{C}$.
Similar results were received for cylindrical probe $50 \mathrm{~mm}$ diameter quenched in $5 \%$ water $\mathrm{NaOH}$ solution at $20{ }^{\circ} \mathrm{C}$ (see Fig. 6 and Fig. 7).

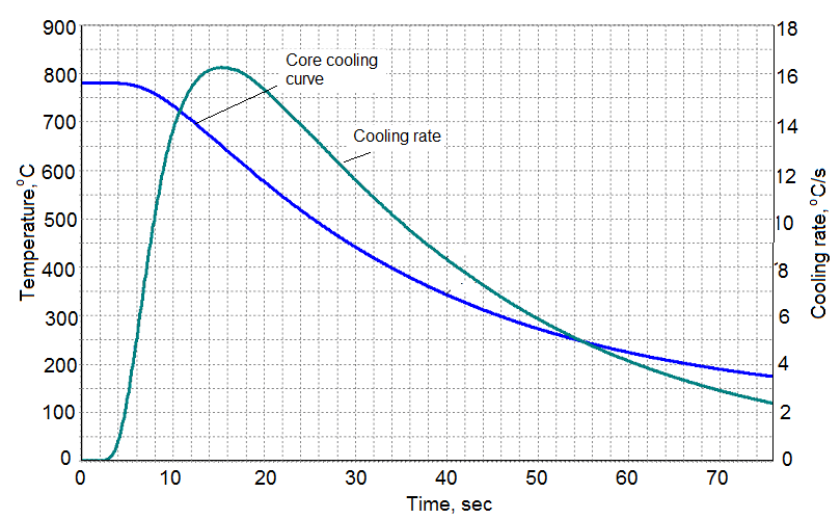

Fig. 6. Cooling curves and cooling rate versus time during quenching cylindrical probe $50 \mathrm{~mm}$ diameter in $5 \%$ water solution of $\mathrm{NaOH}$ at $20^{\circ} \mathrm{C}$.

From both experiments one can come to conclusion that nucleate boiling process develops very intensive quenching and creates huge temperature gradients. Unfortunately, investigators who use only one thermocouple at the core of probe cannot come to conclusion that IQ process can be performed in still quenching media. Especially it refers to those who operate with effective heat transfer coefficients.

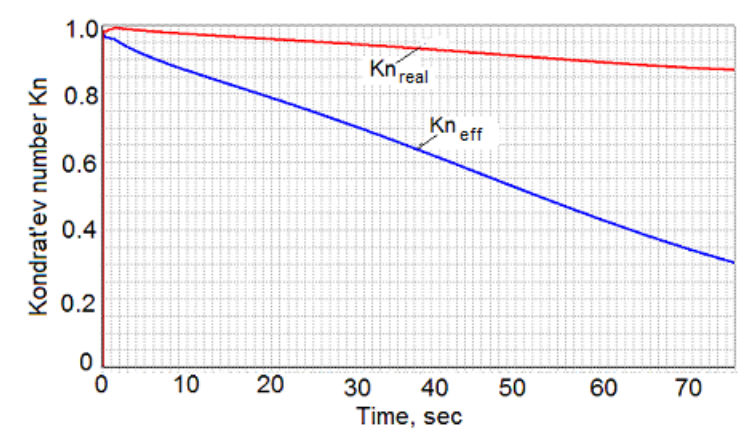

Fig. 7. Real and effective Kondrat'ev numbers versus time during quenching cylindrical probe $50 \mathrm{~mm}$ diameter in $5 \%$ water solution of $\mathrm{NaOH}$ at $20^{\circ} \mathrm{C}$.

Table VI compares real and effective Kondrat'ev numbers $\mathrm{Kn}$ related to quenching $12.5 \mathrm{~mm}$ and $50 \mathrm{~mm}$ cylindrical probes in $5 \%$ water solution of $\mathrm{NaOH}$ at $20{ }^{\circ} \mathrm{C}$ to see whether cooling belongs to intensive quenching (IQ) process.

TABLE VI: REAL AND EFFECTIVE KONDRAT'EV NUMBERS $K N$ FOR CYLINDRICAL PROBES QUENCHED FROM $850^{\circ} \mathrm{C}$ IN 5\% WATER SOLUTION OF NAOH AT $20^{\circ} \mathrm{C}$ WHEN CONVECTIVE HTC IS $500 \mathrm{~W} / \mathrm{m}^{2} \mathrm{~K}$

\begin{tabular}{cccccc}
\hline $\begin{array}{c}\text { Dia, } \\
\mathrm{mm}\end{array}$ & $\begin{array}{c}\text { Type of } \\
\mathrm{Kn}\end{array}$ & $K n_{I}$ & $K n_{I I}$ & $\begin{array}{c}K n_{I}+ \\
\left.K n_{I I}\right) / 2\end{array}$ & $\begin{array}{c}\mathrm{HTC}, \\
\mathrm{W} / \mathrm{m}^{2} \mathrm{~K}\end{array}$ \\
\hline \multirow{2}{*}{12.5} & Real & 0.95 & 0.81 & 0.88 & 20420 \\
& Effective & 0.90 & 0.225 & 0.562 & 3956 \\
\multirow{2}{*}{50} & Real & 1.0 & 0.87 & 0.935 & 9660 \\
& Effective & 0.96 & 0.3 & 0.63 & 1288 \\
\hline
\end{tabular}

As seen from Table VI, average real Kondrat'ev numbers for both $12.5 \mathrm{~mm}$ and $50 \mathrm{~mm}$ probes are higher than 08 that belong to intensive quenching process as it was mentioned above. Note that real Kondrat'ev numbers $K n$ are responsible for temperature gradient evaluation while effective Kondrat'ev number can be used only for 
approximate core cooling time evaluation. It cannot be used for a temperature gradients calculation.

Thus, cooling from high temperatures in $\mathrm{NaCl} ; \mathrm{NaOH}$; $\mathrm{NaNO}_{2} ; \quad \mathrm{NaNO}_{3} ; \quad \mathrm{Na}_{2} \mathrm{CO}_{3} ; \mathrm{CaCl}_{2} ; \mathrm{MgCl}_{2}$ of optimal concentration and in low concentration of inverse solubility polymers is intensive quenching process within initial temperature $T_{o}$ and saturation temperature Ts. Moreover, listed solutions can replace each other to provide almost the same temperature fields during quenching if any film boiling process is completely absent. Differences between listed solutions are critical heat flux densities. More information is provided below (see Table VII and Tabler VIII).

TABLE VII: CORE TEMPERATURE, COOLING RATE, REAL AND EFFECTIVE KONDRAT'EV NUMBERS VERSUS TIME DURING QUENCHING STANDARD PROBE 12.5 MM IN ELECTROLYTES OF OPTIMAL CONCENTRATION WHEN HTC CONV IS EQUAL $500 \mathrm{~W} / \mathrm{m}^{2} \mathrm{~K}$

\begin{tabular}{ccccc}
\hline Time, $\mathrm{s}$ & $\begin{array}{c}\text { Temperature, } \\
{ }^{\circ} \mathrm{C}\end{array}$ & $\begin{array}{c}\text { Cooling } \\
\text { rate, }{ }^{\circ} \mathrm{C} / \mathrm{s}\end{array}$ & $K n_{\text {eff }}$ & $K n_{\text {real }}$ \\
\hline 0 & 850 & 0 & 0 & 0 \\
0.5 & 835 & 135 & 0.850 & 0.928 \\
1.0 & 715 & 278 & 0.802 & 0.931 \\
1.5 & 583 & 245 & 0.771 & 0.947 \\
2 & 472 & 198 & 0.694 & 0.930 \\
2.5 & 485 & 154 & 0.619 & 0.912 \\
3.0 & 317 & 118 & 0.543 & 0.893 \\
3.5 & 266 & 89 & 0.467 & 0.872 \\
4.0 & 227 & 67 & 0.397 & 0.851 \\
4.5 & 198 & 51 & 0.333 & 0.831 \\
5.0 & 176 & 38 & 0.278 & 0.815 \\
5.5 & 160 & 29 & 0.232 & 0.803 \\
5.7 & 181 & 26.4 & 0.217 & 0.801 \\
\hline
\end{tabular}

TABLE VIII: CORE TEMPERATURE, COOLING RATE, REAL AND EFFECTIVE KONDRAT'EV NUMBERS VERSUS TIME DURING QUENCHING CYLINDRICAL PROBE 50 MM IN ELECTROLYTES OF OPTIMAL CONCENTRATION WHEN HTCCONV IS EQUAL $500 \mathrm{~W} / \mathrm{m}^{2} \mathrm{~K}$

\begin{tabular}{ccccc}
\hline Time, $\mathrm{s}$ & $\begin{array}{c}\text { Temperature, } \\
{ }^{\circ} \mathrm{C}\end{array}$ & $\begin{array}{c}\text { Cooling } \\
\text { rate, }{ }^{\circ} \mathrm{C} / \mathrm{s}\end{array}$ & $K n_{\text {eff }}$ & $K n_{\text {real }}$ \\
\hline 0 & 850 & 0 & 0 & 0 \\
10 & 797 & 15 & 0.867 & 0.973 \\
20 & 620 & 16.9 & 0.787 & 0.958 \\
30 & 472 & 12.7 & 0.703 & 0.943 \\
40 & 365 & 9.10 & 0.611 & 0.925 \\
50 & 288 & 6.43 & 0.515 & 0.906 \\
55 & 258 & 5.38 & 0.469 & 0.897 \\
60 & 234 & 4.50 & 0.423 & 0.887 \\
65 & 213 & 3.78 & 0.381 & 0.879 \\
70 & 19.6 & 3.17 & 0.341 & 0.871 \\
75 & 181 & 2.67 & 0.305 & 0.865 \\
\hline
\end{tabular}

In heat treating industry cooling characteristic of quenchant is represented by core cooling curve and core cooling rate of standard cylindrical Inconel 600 probe $12.5 \mathrm{~mm}$ diameter [19]. Thermocouple is located at the center of the standard probe that creates certain difficulties when solving inverse problem to evaluate heat transfer coefficients. Authors [4] used regular thermal condition theory and cooling rate curves to evaluate average HTCs which allow approximately calculate core cooling time of different steel parts during quenching in liquid media. It was underlined many times that such approach cannot be used for accurate temperature fields' calculations. Now, there is an opportunity to see what average HTCs are. We will use cooling curve rates of standard probe (see Fig. 4).

As known, cooling rate is evaluated by (9) [4], [15], [16]:

$$
v=\frac{a K n}{K}\left(T-T_{m}\right)
$$

or

$$
K n=\frac{v K}{a\left(T-T_{m}\right)}
$$

The real Kondrat'ev number $\mathrm{Kn}$ is calculated as:

$$
K n=\frac{v K}{a\left(T-T_{s}\right)}
$$

In heat treating industry, historically, engineers use effective HTCs which could be low enough to satisfy condition $q \leq 0.2$ where core temperature and surface temperature are approximately equal. In fact, it cannot be because transient nucleate boiling process is very intensive.

Currently, as a rule, intensive quenching (IQ) is performed using powerful pumps and electro motors with powerful propellers. During batch quenching water solution flow, developed by rotating propellers, eliminates film boiling process and increases convection. Unfortunately, due to hydrodynamic resistance, liquid flow does not eliminate completely film boiling processes. In 2012 author [20], [21] come to conclusion that thin surface polymeric layer, formed during quenching in low concentration of inverse solubility polymers, decreases initial heat flux density below its critical value that eliminates any film boiling process without pumping and rotating propellers. Moreover, in this paper it is shown that water salt solutions of optimal concentration and low concentration of PAG solution (usually 1\%) develop of IQ process during nucleate boiling mode. Temperature fields during quenching in all mentioned solutions are similar. First, that means dropping surface temperature within 1-2 seconds close to boiling point of a liquid and maintaining surface temperature relatively a long time at the level of boiling point, often called the self- regulated thermal process (SRTP). The duration of SRTP does not depend on inner characteristics of nucleate boiling process.

Due to developed new approach in exploring water polymer solutions, the new problem is arising such as:

- Requirements in investigation behavior of thin surface insulating polymeric layer during steel quenching.

- Requirements in investigation thermal and physical properties of polymeric insulating layer.

- Requirements in investigation of critical heat flux densities during quenching in liquid media.

- Need in designing new database for quenchants and quenching technology.

Experimental and numerical calculations support discussion above. Using French's experimental data [22] regarding cooling different samples from $875^{\circ} \mathrm{C}$ to $150{ }^{\circ} \mathrm{C}$ and equations (1)-(5), core cooling curve and core cooling rate were calculated which are shown in Fig. 8. 


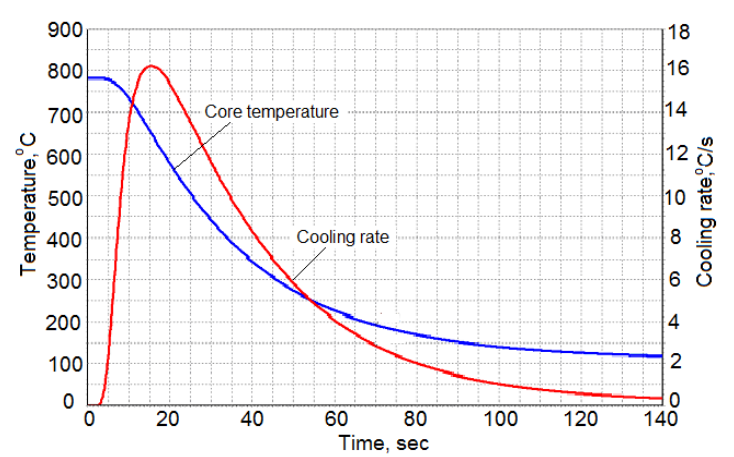

Fig. 8. Core cooling curve and cooling rate curve versus time obtained by computer simulation of quenching cylindrical probe $50 \mathrm{~mm}$ diameter in $1 \%$ water PAG solution at $23^{\circ} \mathrm{C}$.

Core cooling curve and core cooling rate during quenching probe $50 \mathrm{~mm}$ diameter in $1 \%$ water PAG solution, obtained by authors [9], are shown in Fig. 9 which coincides well with calculated data shown in Fig. 8.

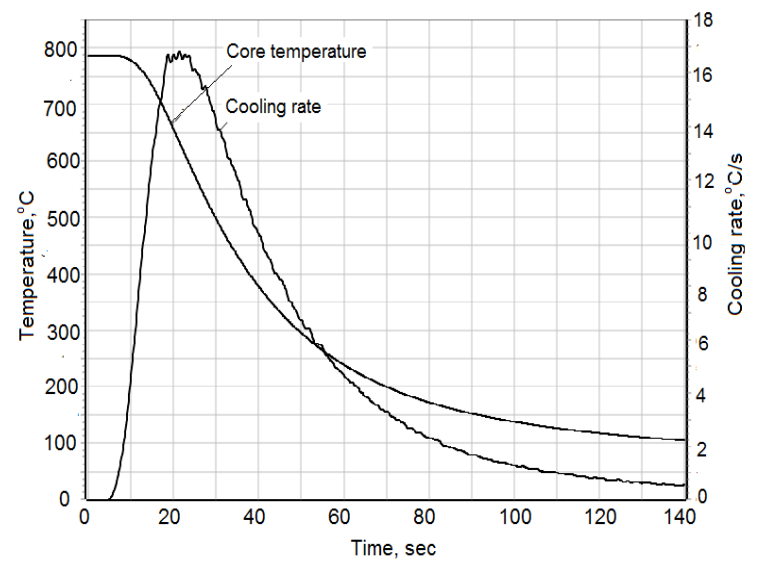

Fig. 9. Core cooling curve and cooling rate curve versus time obtained during quenching cylindrical probe $50 \mathrm{~mm}$ diameter in $1 \%$ water PAG solution at $23{ }^{\circ} \mathrm{C}[9]$.

Thus, intensive quenching processes one can perform in still or low agitated water salt solutions of optimal concentration and low concentration of PAG solutions if any film boiling is completely absent and critical heat flux densities are maximal [23]-[25]. The principal scheme for perfuming IQ process in slow agitated water solutions is shown in Fig. 10 and Fig. 11.

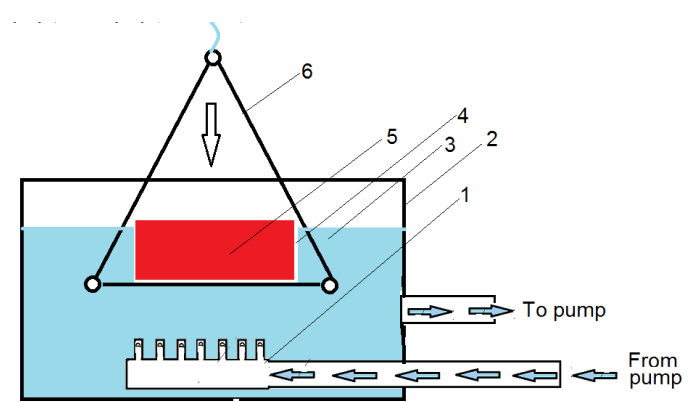

Fig. 10. Quench tank with emitters for slow quenchant agitation and generating resonance effect: 1 is hydrodynamic emitter; 2 is quench tank;

3 is quenchant; 4 is vapor film; 5 is steel part; 6 is lifting system.

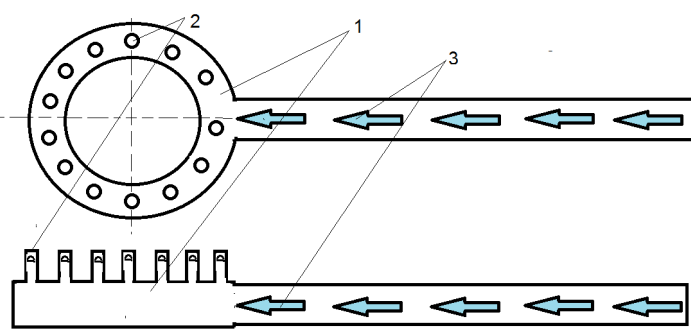

Fig. 11. Platform for placement emitters: 1 is platform; 2 is liquid flow; 3 are hydrodynamic emitters.

The proposed IQ process works perfectly when martensite starts temperature $M_{s}>T_{s}$. If saturation temperature $T_{s} \geq M_{s}$, intensive austempering process via cold liquids can be successfully performed to eliminate slow cooling of molten salts and alkalis [7].

Note that many types of hydrodynamic emitters can be used for quenching purposes.

\section{CONCLUSION}

Intensive quenching process can be performed in still or low agitated water salt solutions of optimal concentration or in low concentration (1\%) water PAG polymer solutions if any film boiling process is completely absent. There is a need to investigate critical heat flux densities of different quenchants as a main parameter of cooling liquid to eliminate effectively film boiling processes during quenching.

\section{REFERENCES}

[1] Kobasko, N. I., Steel Quenching in Liquid Media Under Pressure, Naukova Dumka, Kyiv, 1980. 206 p.

[2] Kobasko, N. I., W. S. Morhuniuk, and B.K. Ushakov, Designing of Steel Intensive Quench Processes, Handbook of Metallurgical Process Design, G. Totten, K. Funatani, and Lin Xie, Eds., Marcel Dekker, New York, 2004, pp. 733-764.

[3] Kobasko, N. I., W. S. Morhuniuk, and A. P. Morganyuk, Hardening of Complex Configuration Bodies by Intensive Cooling, Proceedings of the 7th International Congress on Heat Treatment of Materials, December 11-14, 1990, Moscow, Vol. 2, 1990, pp. 232-239.

[4] Kobasko, N.I., Aronov M. A., Powell J. A., Totten G. E., "Intensive Quenching Systems: Engineering and Design”. ASTM International, USA, 2010. 234 p. doi: 10.1520/mnl64-eb.

[5] Tolubinsky, V. I., Teploobmen pri kipenii (Heat transfer at boiling), Naukova Dumka, Kyiv, 1980, 316.

[6] Mikheev, M. A., and I. M. Mikheeva, Osnovy teploperedachi (Basics of heat transfer), Energy, Moscow, 1977.

[7] Kobasko, N., Austempering processes that are performed via cold liquids, Lambert Academic Publishing, Germany, 2019, 116 p. IBSN: 978-620-0-113-30-6.

[8] Martin, H, Impinging Jets, Hemisphere Handbook of Heat Exchanger Design, G. F. Hewitt, Coordinating Ed., Hemisphere, New York, 1990, pp. 2,5. 6-1.

[9] Kobasko, N.I., Moskalenko,A.A., Logvinenko, P.N, Dobryvechir, V.V., New direction in liquid quenching media development, Теплофізика та теплоенерг етика, 2019, т. 41, №3 pp. 33-40.

[10] Kobasko N., Advanced quenching technologies, Lambert Academic Publishing, Germany, 2021, 126 p. ISBN: 978-620-3-47191-5.

[11] Kobasko, N.I., Uniform and Intense Cooling During Hardening Steel in Low Concentration of Water Polymer Solutions. American Journal of Modern Physics. Vol. 8, No. 6, 2019, pp. 76-85. doi: 10.11648/j.ajmp.20190806.11.

[12] Nozdrev B.F, Senkevich AA. Course of Statistical Physics. Vysshaya Shkola, Moscow, 1969.

[13] Frenkel, Ya. I., Kinetic Theory of Liquids, Selected Works, Vol. 3, Academy of Sciences of the USSR, Moscow, 1959. 
[14] Fedorov, V. I., Kovalenko, G. V. and Kostanchuk, D. M, On the Issue of Boiling Up a Liquid on a Metal Surface, IFZh, Vol. 32, No. 1, 1977, pp. 18-23.

[15] Kondrat'ev, G. M., Regulyarnyi Teplovoy Rezhim (Regular Thermal Mode), Gostekhizdat, Moscow, 1954, 364.

[16] Kondrat'ev, G. M., Teplovye Izmereniya (Thermal measurements), Mashgiz, Moscow, 1957, 250.

[17] Lykov, A. V., Teoriya Teploprovodnosti (Theory of heat conductivity), Vysshaya Shkola, Moscow, 1967, 600.

[18] Kobasko, N. I., Quenching Apparatus and Method for Hardening Steel Parts, U.S. Patent No. 6,364,974 BI, April 2, 2002.

[19] Totten, G.E., Bates, C.E., and Clinton, N.A., Handbook of Quenchants and Quenching Technology, ASM International, Materials Park, OH, 1993, 507 p.

[20] Kobasko, N. I. (2012). Real and Effective Heat Transfer Coefficients (HTCs) Used for Computer Vol. 1, Issue Simulation of Transient Nucleate Boiling Processes During Quenching. Materials Performance and Characterization, 1, 1-20. doi: 10.1520/mpc-20120012.

[21] Kobasko, N., Designing of advanced and original austempering processes based on thermal science and engineering physics approaches, EUREKA: Physics and Engineering, Number 2, 2016, pp.43-50.

[22] French, H. J., The Quenching of Steels, American Society for Steel Treating, Cleveland, OH, 1930.

[23] Kutateladze, S. S., Fundamentals of Heat Transfer, Academic Press, New York, 1963.

[24] Kobasko, N. I., A. A. Moskalenko, G. E. Totten, and G. M. Webster, Experimental Determination of the First and Second Critical Heat Flux Densities and Quench Process Characterization, Journal of Materials Engineering and Performance, Vol. 6, No. 1, 1997, pp. 93101.

[25] Kobasko N.I., A universal correlation for the calculation of heating and cooling time of any steel, Materials Performance and Characterization, 2017, Vol. 6, No. 1, pp. 551-565. doi: 10.1520/MPC20170034. Available online at www.astm.org. 